\title{
Impact of early surgical correction or palliation of congenital heart defects in infants with symptomatic viral respiratory tract infections in the current era
}

Nick A. Giffin, MD, MSc, FRCPC, ${ }^{a}$ Gonzalo Guerra, MD, MSc, PhD, FRCPC, ${ }^{b}$ Joan Robinson, MD, FRCPC, ${ }^{c}$ Chloe Joynt, MD, MSc, FRCPC, ${ }^{\mathrm{d}}$ Ivan Rebeyka, MD, FRCSC, ${ }^{\mathrm{e}}$ and V. Ben Sivarajan, MD, MS, FRCPC ${ }^{\mathrm{b}}$

\section{ABSTRACT}

Objective: This study investigates the influence of timing of surgery among infants with congenital heart disease and active respiratory tract infections in a contemporary Western Canadian cohort.

Methods: This was a retrospective matched cohort study of infants aged 1 week to 6 months undergoing surgical repair of congenital heart disease between 2014 and 2017. Case patients had active respiratory tract infections preoperatively and were matched to control patients based on primary heart lesion. The primary outcome was time to extubation.

Results: We identified 20 cases (median age, 3.4 months [range, 2.4-4.3 months]) that were matched to 40 controls (1:2 ratio). In case patients, surgery occurred at a median of 1 day after the positive viral testing. There were no statistically significant differences between cases and controls in time to extubation (59 vs 34 hours $[P=.12]$ ), postoperative vasoactive scores at 24 hours (o vs $\circ[P=.53]$ ), 48 hours (O vs O $[P=.23]$ ), maximum vasoactive score in postoperative period (5 vs 5.5 $[P=.54]$ ), or time to hospital discharge (13 vs 12 days $[P=.39]$ ). Case patients had increased duration of total respiratory support (including noninvasive ventilation, 3.5 vs 2 days $[P=.02]$ ) and postoperative intensive care unit length of stay (5.5 vs 3 days $[P=.01])$.

Conclusions: Cardiac surgery on infants with congenital heart disease during an acute viral respiratory tract infection may yield a clinically relevant prolongation in time to extubation. (JTCVS Open 2021;6:211-9)

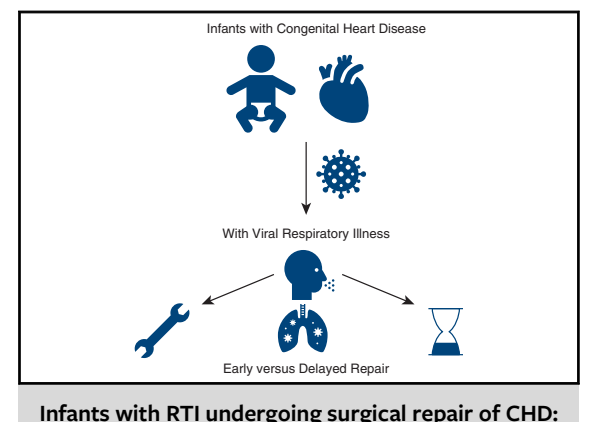

Time to extubation versus controls.

CENTRAL MESSAGE

Cardiac surgery on infants with CHD during an acute viral RTI resulted in a clinically relevant prolongation in time to postoperative extubation that did not reach statistical significance.

\section{PERSPECTIVE}

Convention suggests postponement of cardiac surgery for 4 to 6 weeks after viral respiratory tract infections in infants with congenital heart disease. Our findings suggest earlier surgery can be considered without significant prolongation in time to hospital discharge. However, it may result in longer time to extubation, postoperative intensive care length of stay, and total duration of respiratory support.

See Commentary on page 220.

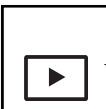

Video clip is available online.

From the ${ }^{a}$ Division of Pediatric Emergency Medicine, ${ }^{b}$ Pediatric Cardiac Intensive Care Unit, Division of Pediatric Critical Care, ${ }^{\mathrm{c}}$ Division of Pediatric Infectious Diseases, ${ }^{\mathrm{d}}$ Division of Neonatology, and ${ }^{\mathrm{e}}$ Division of Pediatric Cardiac Surgery, Stollery Children's Hospital, University of Alberta, Edmonton, Alberta, Canada. Supported by a grant to Drs Giffin and Sivarajan from the Women and Children's Health Research Institute, University of Alberta, Edmonton, Alberta, Canada.

Accepted for the 46th Annual Meeting of the Western Thoracic Surgical Association.

Received for publication March 17, 2021; accepted for publication March 17, 2021; available ahead of print April 21, 2021.
Symptomatic viral respiratory tract infections (RTIs) represent a significant portion of acute care provided to pediatric populations and are more severe in those with congenital heart disease (CHD) with regard to severity of illness. ${ }^{1-3}$

\footnotetext{
Address for reprints: V. Ben Sivarajan, MD, MS, FRCPC, PCICU, Stollery Children's Hospital, University of Alberta, Edmonton Clinic Health Academy, 11405-87 Ave, Edmonton, Alberta T6G 1C9 Canada (E-mail: ben.sivarajan@ ualberta.ca).

2666-2736

Copyright (c 2021 The Author(s). Published by Elsevier Inc. on behalf of The American Association for Thoracic Surgery. This is an open access article under the CC BY-NC-ND license (http://creativecommons.org/licenses/by-nc-nd/4.0/). https://doi.org/10.1016/j.xjon.2021.03.009
} 


$$
\begin{aligned}
& \text { Abbreviations and Acronyms } \\
& \begin{aligned}
\text { CHD } & =\text { congenital heart disease } \\
\text { ICU } & =\text { intensive care unit } \\
\text { NPA } & =\text { nasopharyngeal aspirate } \\
\text { PCICU } & =\text { pediatric cardiac intensive care unit } \\
\text { RSV } & =\text { respiratory syncytial virus } \\
\text { RTI } & =\text { respiratory tract infection } \\
\text { VIS } & =\text { vasoactive inotropic score } \\
\text { WCCHN } & =\text { Western Canadian Congenital Heart } \\
& \text { Network }
\end{aligned}
\end{aligned}
$$

There have been concerns with both increased mortality and morbidity when surgery for CHD is performed during active upper and lower viral RTI. ${ }^{4-6}$ In 1999, Khongphatthanayothin and colleagues ${ }^{6}$ examined the outcomes of cardiac surgery for CHD in the setting of respiratory syncytial virus (RSV) infections. They compared outcomes of early cardiac surgery during an admission for RSV infection $(n=13)$ to those with delayed surgery after a recent ( $<6$ months) discharge for RSV infection $(n=12)$. Complications in the early surgical group included increases in time to extubation, length of hospital stay, higher rates of postoperative pulmonary hypertension and 2 deaths. Based on this limited evidence, a common practice has developed to delay cardiac surgery for 4 to 6 weeks in patients with active RTI. Contemporary studies in children with CHD and viral RTI undergoing cardiac surgery have demonstrated increased postoperative duration of intubation, total respiratory support, and intensive care unit (ICU) length of stay without an attendant increase in mortality. ${ }^{7-10}$

The Stollery Children's Hospital is the Western Canadian referral center for complex pediatric cardiac surgery and serves a referral population of 12 million people in 4 provinces and 2 territories through 5 tertiary referral sites as part of the Western Canadian Congenital Heart Network (WCCHN). The WCCHN is based in a northern latitude where the season for respiratory infections is protracted, leading to many surgical cancellations due to RTIs. We hypothesize that in our current era, patients with RTIs undergoing surgery for $\mathrm{CHD}$ have similar postoperative outcomes to those without.

\section{METHODS}

We performed a single-center, matched cohort study. This study was approved by the University of Alberta Health Research Ethics Board (MS2_Pro00070267) with the requirement for individual consent waived. Eligible cases and controls were infants with chronological age 1 week to 6 months undergoing surgery for CHD and managed postoperatively in the Stollery Children's Hospital Pediatric Cardiac Intensive Care Unit (PCICU) or Neonatal Intensive Care Unit from 2014 through 2017. They were identified from health records (WCCHN registry data, electronic medical record, and physical chart). Viral RTI cases had clinical symptoms of RTI within 4 weeks before surgery and a virus detected on nasopharyngeal specimen. Infectious symptoms were defined as any combination of fever, cough, change in respiratory secretions, or deterioration in respiratory status (ie, increased work of breathing or escalation of respiratory support with corroborating infectious symptoms). Infants were excluded if upon chart review, respiratory symptoms were deemed to be more likely related to progression of underlying cardiac disease than to RTI (ie, primary symptoms were more in keeping with congestive heart failure, such as hepatic or pulmonary congestion, peripheral edema, or decline in heart function). Infants younger than age 7 days at the time of surgery were excluded from the search because they were presumed to be at low risk of having developed a symptomatic RTI.

Two controls were matched to each viral RTI case using the WCCHN registry. The registry was searched for all patients with chronological age 1 week to 6 months who underwent cardiac surgery, and sorted based on predominant cardiac lesion (ie, transposition of the great arteries, tetralogy of Fallot, single-ventricle physiology, shunt lesions [eg, atrial septal defect, ventricular septal defect, atrioventricular septal defect, or patent ductus arteriosus], anomalous pulmonary venous return, and ventricular outflow lesions [eg, interrupted aortic arch, coarctation of the aorta, or pulmonary atresia]), and then surgery type (initial vs reoperation, palliative [eg, shunt placement] vs reparative). Controls were then selected from the registry list based on chronologic order within the study time frame if there were multiple candidates for matching. They were excluded if they had any documented RTI symptoms or positive nasopharyngeal aspirate (NPA) during the 4 weeks before surgery. Preoperative comorbidities were not screened for before inclusion in either case patients or control patients.

For case patients and control patients, the covariates collected included age, sex, type of heart defect, surgical procedure, surgical intent (palliative vs reparative), initial versus repeat surgery, and the use of cardiopulmonary bypass. The primary outcome of interest was time to extubation after surgical intervention. Secondary outcomes of interest were total duration of postoperative respiratory support (ie, defined as both invasive mechanical ventilation and noninvasive ventilation such as biphasic positive airway pressure, continuous positive airway pressure, or high-flow nasal cannula), vasoactive inotrope scores (VIS) ${ }^{11}$ (maximum during postoperative period, at 24 and at 48 hours postoperatively), postoperative complications (eg, ventilator-associated pneumonia, need for reintubation, use of extracorporeal membrane oxygenation or cardiac arrest), postoperative ICU length of stay, postoperative hospital length of stay, and mortality. Data were collected on a standardized, anonymized data form and subsequently entered into the Research Electronic Data Capture system (REDCap Consortium, Vanderbilt University, Nashville, Tenn). ${ }^{12,13}$

\section{Statistical Analysis}

Categorical data are presented as counts and percentages whereas continuous data are presented as medians and interquartile ranges. Comparison between the 2 groups utilized nonparametric statistical analyses using Mann-Whitney, $\chi^{2}$ and Fisher exact tests as appropriate. All $P$ values were 2 -sided. Data were analyzed using nonparametric methods for independent data because cases were not exactly matched to controls due to limitations in the available number of controls. All analyses were performed using STATA version 15.1 (StataCorp LLC, College Station, Tex).

\section{RESULTS}

During the study period, 424 eligible infants were identified from 1628 operative cardiac procedures (Figure 1). Respiratory viruses were detected within 4 weeks preoperatively in 37 infants. In 13 of the 37 infants, there was no documentation of RTI symptoms and the infants were excluded. Additional patients were excluded because the chart was not available $(\mathrm{n}=1)$, the surgery was not cardiac $(\mathrm{n}=1$; thoracic duct ligation), and control patients could not be identified ( $\mathrm{n}=2$; both patients had anomalous left 


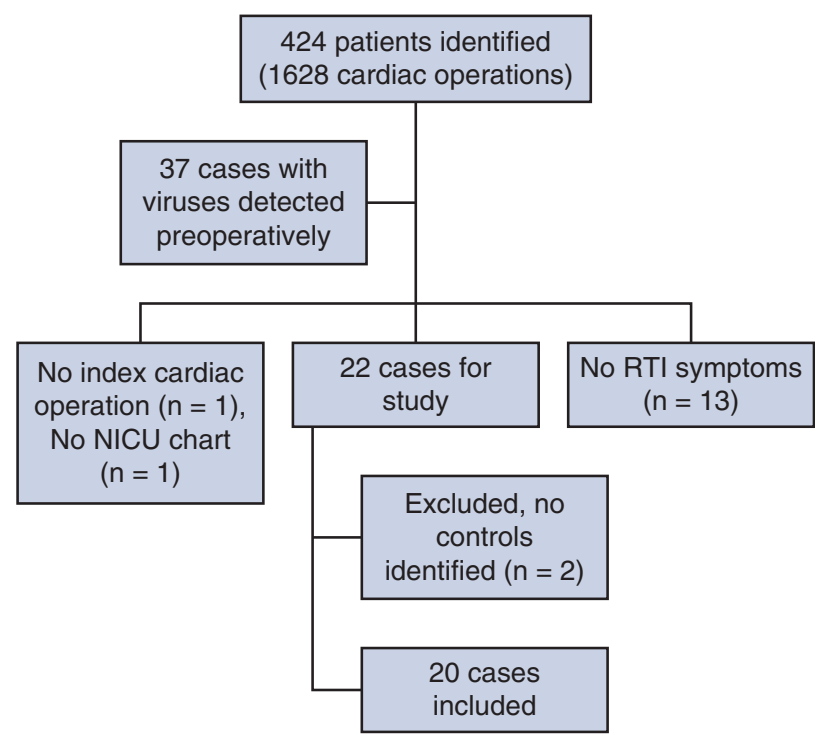

FIGURE 1. Case patients (aged 1 week to 6 months) were identified from the Western Canadian Congenital Heart Network (WCCHN) and cross referenced against positive nasopharyngeal aspirate (NPA) results within 4 weeks of surgery date. Patients with no description of clinical symptoms in the medical record were excluded. Control patients were identified from the WCCHN registry based on surgical intervention and without symptoms of viral respiratory tract infection $(R T I)$. NICU, Neonatal intensive care unit.

coronary artery from pulmonary artery with ventricular assist devices), leaving 20 cases for study (Table 1).

There were no statistically significant differences in baseline characteristics between groups in regard to age, preterm status, weight, or use of cardiopulmonary bypass (Table 2). All comparators are described in median values and interquartile ranges. Difference in time to extubation between viral RTI patients and controls did not reach statistical significance (59 vs 34 hours $[P=.12]$ ). There were no differences in other secondary outcomes, including VIS at 24 hours postoperatively ( 0 vs $0[P=.53])$, 48 hours postoperatively ( 0 vs $0[P=.23]$ ), maximum VIS during postoperative period (5 vs $5.5[P=.54]$ ), or time to hospital discharge (13 vs 12 days $[P=.39])$. However, patients with viral RTIs had a significant increase in the duration of postoperative total respiratory support (3.5 vs 2 days $[P=.02])$ and in the duration of postoperative ICU length of stay (5.5 vs 3 days $[P=.01])$. There were no statistically significant differences in postoperative complications between groups (Table 3). Reintubation was required in 2 patients in each group. One patient in the viral RTI group had 2 postoperative cardiac arrests related to atrioventricular blockade and required both cardiopulmonary resuscitation and antiarrhythmic medications. There were 4 patients in the viral RTI group who were diagnosed with nosocomial, ventilator-associated pneumonia during the postoperative period; there were 2 such patients in the control group. Finally, there were no deaths or need for postoperative extracorporeal membrane oxygenation in either group (Table E1).

\section{DISCUSSION}

In this matched cohort study, we describe a contemporary cohort of symptomatic infants with RTI and viral

Influence of early surgical correction/palliation of congenital heart defects in infants with symptomatic viral respiratory tract infections in the current era

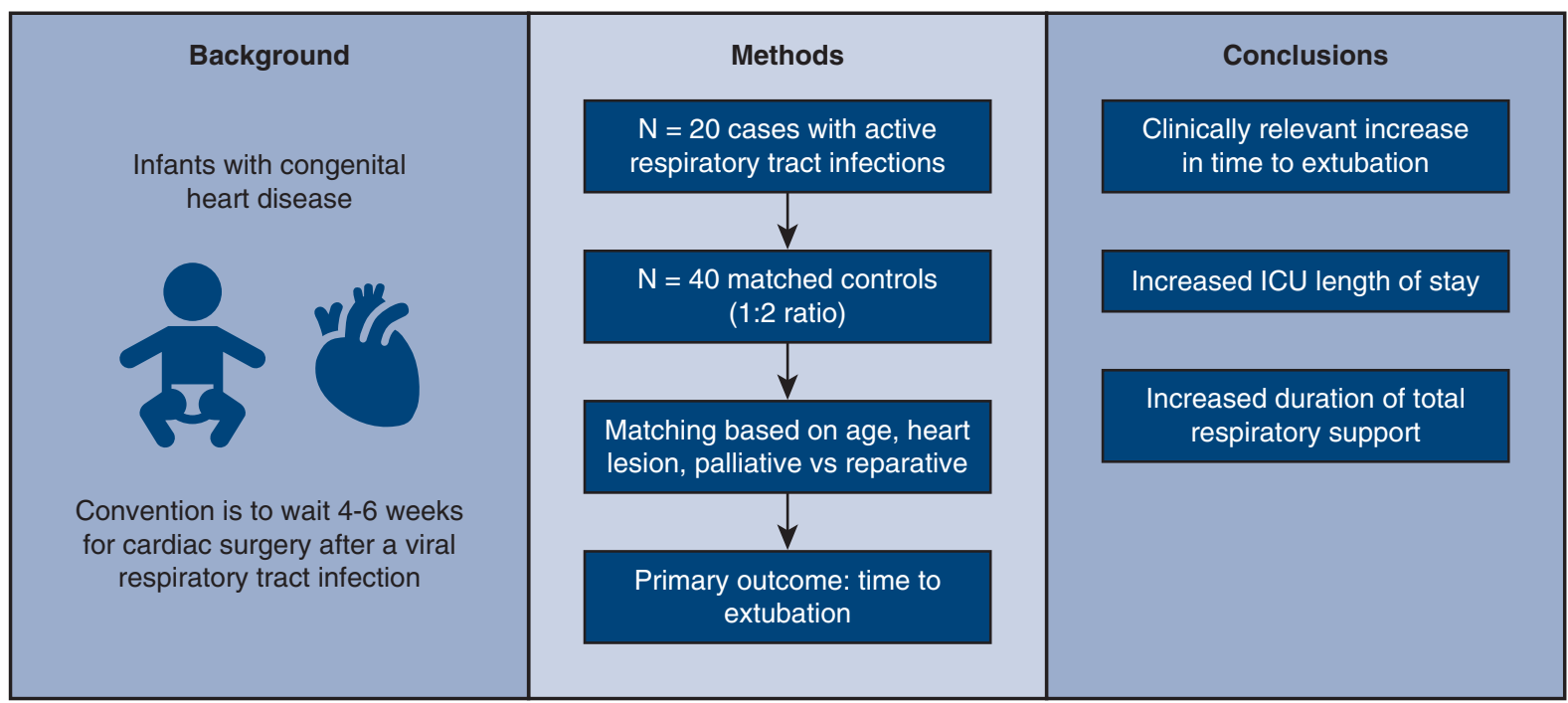

FIGURE 2. Background, study methods, and study conclusions. Infants (aged 1 week to 6 months) with congenital heart disease and active and viral respiratory tract infections (RTIs) preoperatively were matched in a 1:2 fashion to controls based on predominant heart lesion. Viral RTI cases were found to have a statistically insignificant, although clinically relevant increase in time to extubation compared with matched controls. Case patients also had an increased intensive care (ICU) length of stay and total duration of respiratory support (total time of intubation plus noninvasive support). 
TABLE 1. Baseline characteristics for cases of viral respiratory tract infection before cardiac surgery

\begin{tabular}{|c|c|c|c|c|c|}
\hline Heart lesion & Surgical procedure & Symptoms & NPA result & $\begin{array}{c}\text { NPA to } \\
\text { surgery* }^{*}(d)\end{array}$ & $\begin{array}{l}\text { Symptoms to } \\
\text { surgery } \dagger \text { (d) }\end{array}$ \\
\hline $\begin{array}{l}\text { TGA, VSD, PS, single left } \\
\text { coronary artery }\end{array}$ & Central shunt & $\begin{array}{l}\text { Sneezing, coughing, nasal } \\
\text { congestion }\end{array}$ & Coronavirus & Day of $\ddagger$ & Day of $\ddagger$ \\
\hline $\begin{array}{l}\text { Double inlet left ventricle, } \\
\text { VSD, PA, PDA, } \\
\text { hypoplastic right ventricle, } \\
\text { post-Norwood/Sano/Glenn }\end{array}$ & Blalock-Taussig shunt & Cough, congestion & Parainfluenza & 3 & Day of $\ddagger$ \\
\hline AVSD, LAVV regurgitation & ASD repair, LAVV repair & $\begin{array}{l}\text { Nasal congestion, increasing } \\
\text { oxygen needs }\end{array}$ & Parainfluenza & 19 & 9 \\
\hline AVSD & AVSD repair & Secretions, increased WOB & ERV & 7 & Day of $\ddagger$ \\
\hline DORV, ASD, VSD, PDA & $\begin{array}{l}\text { DORV repair, ASD closure, } \\
\text { VSD closure, PDA ligation }\end{array}$ & $\begin{array}{l}\text { Nasal secretions, progressive } \\
\text { congestive heart failure }\end{array}$ & ERV & Day of $\ddagger$ & Day of $\ddagger$ \\
\hline IAA, hemitruncus, PDA, ASD & $\begin{array}{l}\text { Hemitruncus repair, IAA } \\
\text { repair, ASD repair, PDA } \\
\text { ligation }\end{array}$ & $\begin{array}{l}\text { Increased WOB, desaturation, } \\
\text { right upper lobe } \\
\text { consolidation }\end{array}$ & ERV & 1 & Day of $\ddagger$ \\
\hline $\begin{array}{l}\text { PAPVC, LPA stenosis, PDA, } \\
\text { dilated right ventricle }\end{array}$ & $\begin{array}{l}\text { LPA-plasty, pulmonary } \\
\text { venous baffle, ASD repair, } \\
\text { PDA ligation }\end{array}$ & New secretions & ERV & 4 & Day of $\ddagger$ \\
\hline $\begin{array}{l}\text { Dextrocardia, DORV, PA, } \\
\text { hypoplastic right ventricle, } \\
\text { right aortic arch, ASD, LPA } \\
\text { stenosis }\end{array}$ & Bilateral Glenn & Fever, hypoxemia, cough & ERV & Day of $\ddagger$ & Day of $\ddagger$ \\
\hline $\begin{array}{l}\text { ASD, VSD, RV hypertrophy } \\
\text { with outflow tract } \\
\text { obstruction }\end{array}$ & $\begin{array}{l}\text { VSD patch, suture ASD } \\
\text { repair, RV bundle resection }\end{array}$ & Desaturation, new secretions & ERV & 1 & Day of $\ddagger$ \\
\hline VSD, vascular ring & VSD patch, PDA ligated & Fever, secretions & ERV & Day of $\ddagger$ & Day of $\ddagger$ \\
\hline $\begin{array}{l}\text { PA, VSD, major } \\
\text { aortopulmonary collateral } \\
\text { arteries }\end{array}$ & Central shunt & Desaturation, green secretions & ERV & 1 & Day of $\ddagger$ \\
\hline $\begin{array}{l}\text { VSD, ASD, RV outflow tract } \\
\text { obstruction }\end{array}$ & $\begin{array}{l}\text { VSD patch, ASD repair, } \\
\text { resect RV bundle }\end{array}$ & $\begin{array}{l}\text { Cough, chest radiograph } \\
\text { infiltrates }\end{array}$ & Coronavirus & Day of $\ddagger$ & Day of $\ddagger$ \\
\hline $\mathrm{AS}, \mathrm{CoA}$ & CoA repair & $\begin{array}{l}\text { Nasal secretions, ventilator } \\
\text { changes }\end{array}$ & ERV & Day of $\ddagger$ & Day of $\ddagger$ \\
\hline $\begin{array}{l}\text { CoA, VSD, bicuspid aortic } \\
\text { valve }\end{array}$ & CoA repair & Fever, cough, increased WOB & RSV & 2 & Day of $\ddagger$ \\
\hline TOF, ASD, VSD, PS, PDA & TOF repair & Bronchiolitis & ERV & 23 & 5 \\
\hline $\begin{array}{l}\text { TOF, PS, enlarged pulmonary } \\
\text { arteries }\end{array}$ & TOF repair & $\begin{array}{l}\text { Cough, congestion, cyanosis, } \\
\text { increased WOB }\end{array}$ & ERV & 8 & 2 \\
\hline ASD, VSD, PDA & $\begin{array}{l}\text { ASD repair, VSD patch, PDA } \\
\text { ligation }\end{array}$ & Increased WOB & ERV & 1 & Day of $\ddagger$ \\
\hline PDA & PDA ligation & $\begin{array}{l}\text { Increased secretions, acute } \\
\text { respiratory distress } \\
\text { syndrome }\end{array}$ & Parainfluenza & 10 & 3 \\
\hline CoA, bicuspid aortic valve & CoA repair, PDA ligation & Secretions, stridor & RSV & Day of $\ddagger$ & Day of $\ddagger$ \\
\hline $\begin{array}{l}\text { TOF/PA, major } \\
\text { aortopulmonary collateral } \\
\text { arteries }\end{array}$ & $\begin{array}{l}\text { RV to PA conduit, RPA plasty, } \\
\text { VSD closure }\end{array}$ & $\begin{array}{l}\text { Fever, increased } \mathrm{FiO}_{2}, \\
\text { increased WOB }\end{array}$ & ERV & 1 & Day of $\ddagger$ \\
\hline
\end{tabular}


TABLE 2. Baseline characteristics of infants with congenital heart disease undergoing surgical repair in viral respiratory tract infection case patients versus control patients. Comorbid genetic diagnosis, noninvasive ventilation use, congestive heart failure, and pulmonary hypertension were from documentation in the electronic medical record, not based on specific imaging or laboratory criteria

\begin{tabular}{|c|c|c|c|}
\hline Characteristic & Viral RTI $(n=20)$ & Controls $(n=40)$ & $P$ value \\
\hline Male sex & $10(50)$ & $28(70)$ & .16 \\
\hline Preterm $(<37$ wk GA) & $2(10)$ & $5(13)$ & 1.0 \\
\hline Age at surgery (mo) & $3.4(2.4,4.3)$ & $3.0(2.0,4.2)$ & .36 \\
\hline Neonates $(<1 \mathrm{mo})$ & $0(0)$ & $7(18)$ & .08 \\
\hline Cardiopulmonary bypass & $13(65)$ & $26(65)$ & 1.0 \\
\hline Weight $(\mathrm{kg})$ & $4.77(4.1,5.6)$ & $4.7(3.6,5.5)$ & .57 \\
\hline Chromosomal abnormalities identified at time of surgery & $3(15)$ & $6(15)$ & 1.0 \\
\hline Preoperative noninvasive ventilation use & $0(0)$ & $2(5)$ & .55 \\
\hline Preoperative congestive heart failure & $1(5)$ & $5(13)$ & .65 \\
\hline Preoperative pulmonary hypertension & $0(0)$ & $3(7.5)$ & .54 \\
\hline
\end{tabular}

Values are presented as $\mathrm{n}(\%)$ or median (25th percentile, 75 th percentile). RTI, Respiratory tract infection; GA, gestational age.

confirmation on NPA who underwent early index cardiac surgery (median time from NPA to surgery of 1 day). Although a statistical difference in time to extubation was not identified, viral RTI cases remained intubated for a median 59 hours postoperatively compared with 34 hours in controls, a finding we consider a clinically relevant difference. We also identified an increase in the duration of total respiratory support (including noninvasive ventilation) and postoperative ICU length of stay in viral RTI case patients (Figure 2).

The results of our study contrast to the previously cited study that described an increase in morbidity and mortality with cardiac surgery following RSV infection by Khongphatthanayothin and colleagues. ${ }^{6}$ As a result of the severity of illness and high risk for mortality from RSV infections in infants with CHD (approaching 5\% in some studies), ${ }^{14-16}$ the utility of preoperative RSV screening programs has been examined. ${ }^{7}$ However, during the 20 years since this initial study was published, ${ }^{6}$ there have been significant advances in technologies and expertise utilized during cardiopulmonary bypass and postoperative care for this population such that viral RTI may now be less prohibitive to surgery. Furthermore, expertise in noninvasive ventilation and the use of high-flow nasal cannula have contributed to evolving postoperative respiratory support practices. Importantly in our study, there were only 2 identified RSV cases with the majority of viral pathogens identified being enterorhinovirus. This may suggest an institutional bias for delaying primary cardiac operations on infants with active RSV, although we have no way of retrospectively accounting for cases in which surgery was intentionally delayed. The anesthesia literature supports this conjecture, wherein children with mild RTI are considered safe for anesthesia, whereas those with more severe

TABLE 3. Clinical outcomes of infants with congenital heart disease undergoing surgical repair in viral respiratory tract infection case patients versus control patients

\begin{tabular}{|c|c|c|c|}
\hline Outcome & Viral RTI $(n=20)$ & Control $(n=40)$ & $P$ value \\
\hline Time to extubation (h) & $59(24,96)$ & $34(8,78)$ & .12 \\
\hline Postoperative total respiratory support (d) & $3.5(2.0,6.0)$ & $2.0(1.0,3.0)$ & .02 \\
\hline VIS maximum in postoperative period & $5.0(0.0,10.0)$ & $5.5(0.0,10.0)$ & .54 \\
\hline VIS at $24 \mathrm{~h}$ postoperative & $0.0(0.0,4.0)$ & $0.0(0.0,5.0)$ & .53 \\
\hline VIS at $48 \mathrm{~h}$ postoperative & $0.0(0.0,2.50)$ & $0.0(0.0,5.0)$ & .23 \\
\hline Postoperative ICU length of stay (d) & $5.5(2.0,10.0)$ & $3.0(2.0,5.0)$ & .01 \\
\hline Hospital length of stay (d) & $13(8.0,20.0)$ & $12.0(6.0,16.0)$ & .39 \\
\hline Failure of extubation & $2(10)$ & $2(5)$ & .60 \\
\hline Postoperative VAP & $4(20)$ & $2(5)$ & .09 \\
\hline Postoperative ECMO & $0(0)$ & $0(0)$ & - \\
\hline Postoperative cardiac arrest & $1(5)$ & $1(2.5)$ & 1.0 \\
\hline
\end{tabular}

Values are presented as $\mathrm{n}(\%)$ or median (25th percentile, 75th percentile). RTI, Respiratory tract infection; VIS, vasoactive inotrope score; ICU, intensive care unit; $V A P$, ventilator associated pneumonia; $E C M O$, extracorporeal membrane oxygenation. 


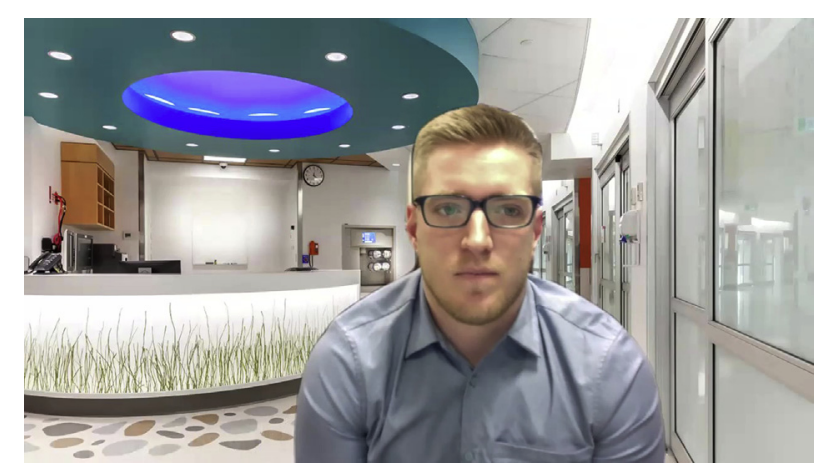

VIDEO 1. Dr Nick Giffin describing the study protocol and results. Video available at: https://www.jtcvs.org/article/S2666-2736(21)00065-6/ fulltext.

symptoms (eg, fever or wheeze) should be delayed for at least 2 weeks. ${ }^{17}$ Given the retrospective nature of this study, we were limited by the documentation available and are therefore not able to provide commentary on the specific decision-making processes to proceed with surgery despite active RSV infections in the 2 cases presented. Although a subgroup analysis could not be completed for each viral species, the 2 patients with RSV did have clinically longer times of intubation (28 and 92 hours) compared with their matched controls ( 8 and 4 hours or 8 and 9 hours, respectively) potentially supporting the delay of cardiac surgery in infants with RSV when practical to do so.

The results of more recent studies are concordant with our study. In 2011, Spaeder and colleagues ${ }^{9}$ completed a case control series of all pediatric patients (younger than age 18 years) with CHD undergoing cardiac surgical intervention looking for seasonal variation in postoperative outcomes. Although no seasonal variation in postoperative course or mortality could be identified, a subgroup analysis demonstrated that those with active viral RTI had both longer hospital admissions and PCICU length of stay when compared with controls. ${ }^{9}$ Moynihan and colleagues ${ }^{10}$ have since presented a larger cohort of cardiac patients younger than age 18 years $(\mathrm{n}=73$ with active RTI). In this study of pediatric patients of all ages, the authors found an increase in PCICU length of stay and duration of respiratory support in those with an active viral RTI. In keeping with our study, the authors found similar outcomes among all patients and when compared with subgroups restricted to infants (younger than age 365 days), as well as when restricted to those requiring cardiopulmonary bypass. The authors identified a prolonged period of intubation in the RTI group. Although we did not identify a statistically significant prolongation of intubation, the viral RTI group described herein had a longer median duration of intubation than the control group by 25 hours, a finding that we consider clinically relevant. Although the sample size from the study by Moynihan and colleagues ${ }^{10}$ was larger than the data presented here, we believe our study represents the true at-risk group; namely those younger than age 6 months with unrepaired shunt lesions or residual unpalliated CHD.

Our findings suggest that surgical correction in the setting of an active RTI might be completed without prolonging time to discharge from hospital. However, postoperative ICU length of stay and total duration of respiratory support were longer in the viral RTI group. As such, the urgency of surgical correction, viral pathogen, geographic location of the patient, and the potential morbidity associated with deferring a cardiac surgical intervention must all be taken into consideration when making clinical decisions for these infants (Video 1).

\section{Limitations}

The primary limitation of this study is the small sample size. We included only symptomatic patients because we sought tight clinicopathological correlation of the diagnosis of RTI. The low numbers of patients yielded a statistically insignificant increase in duration of postoperative intubation (59 vs 34 hours) that we believe is clinically important to consider. In addition, we would have ideally differentiated upper and lower RTI, but it was not possible to reliably do so from the chart review. Second, because we obtained evidence of RTI symptoms based on review of electronic medical records, there is a potential for informative bias. Third, although we matched based on chronological age, primary heart defect, and the surgical intervention, it was not possible to find exact matches for patients with complex heart disease physiology and various other comorbidities (eg, trisomy 21, 22q11.2 deletion syndrome, or prematurity) which could influence the postoperative course. We attempted to address this by matching in a 1:2 fashion, although this certainly does not eliminate the possibility of imprecise matching. We did not match based on patient sex because there is robust data that surgical outcomes in pediatric CHD are not influenced by patient sex. ${ }^{18}$ Fourth, our available molecular testing does not differentiate between enterovirus and rhinovirus, which can admittedly have variability in symptomatology. Fifth, our methodology did not allow us to gauge the severity of illness among RTI cases and it is possible that some surgeries at our center during the study time period were deferred for severe illness or virus type (eg, RSV). Furthermore, patients for whom surgeries were intentionally delayed during the study time period could not be accounted for from our surgical registry data (eg, those from another province awaiting transfer or decision made to delay from outpatient clinic). Sixth, the low number of each virus species did not allow for subgroup analysis based on viral pathogen. Particularly, low numbers of RSV-positive patients ( 2 out of 20 [10\%]), may not provide enough reassurance to advocate for the safety of an early operative approach for this subgroup. Seventh, the 
lack of neonates (younger than age 4 weeks) with active RTI in this study cohort limits the utility of the results presented to that specific population. Finally, this was a single center study, which limits the generalizability of the results.

\section{CONCLUSIONS}

In our center, postponement of cardiac surgery in infants with CHD and viral RTIs is not always practical or achievable based on a patient's clinical status, geography of our catchment area, and the volume of cardiac interventions performed. In this study, an early operative approach did not yield a statistically significant prolongation in time to extubation or hospital length of stay. However, we did identify a clinically important increase in time to extubation, longer duration of postoperative total respiratory support, and ICU length of stay, albeit without evidence of attendant morbidity. Future, prospective studies probing specific viral species, markers of illness severity, and the urgency/ complexity of repair are needed to clearly delineate when pediatric patients may safely undergo cardiac surgery during an acute viral RTI.

\section{Conflict of Interest Statement}

The authors reported no conflicts of interest.

The Journal policy requires editors and reviewers to disclose conflicts of interest and to decline handling or reviewing manuscripts for which they may have a conflict of interest. The editors and reviewers of this article have no conflicts of interest.

\section{References}

1. Meissner CH. Viral bronchiolitis in children. N Engl J Med. 2016;374:62-72.

2. MacDonald NE, Hall CB, Suffin SC, Alexon C, Harris PJ, Manning JA. Respiratory syncytial viral infection in infants with congenital heart disease. $N$ Engl J Med. 1982;307:397-400.

3. Feldman RJ, Fidalgo HC, John JF Jr. Respiratory syncytial virus infection in a cardiac surgery intensive care unit. J Thorac Cardiovasc Surg. 1994;108:1152.

4. Malviya S, Voepel-Lewis T, Siewert M, Pandit UA, Riegger LQ, Tait AR. Risk factors for adverse postoperative outcomes in children presenting for cardiac surgery with upper respiratory tract infections. Anesthesiology. 2003;98:628-32.
5. Delgado-Corcoran C, Witte MK, Ampofo K, Castillo R, Bodily S, Bratton SL. The impact of human rhinovirus infection in pediatric patients undergoing heart surgery. Pediatr Cardiol. 2014;35:1387-94.

6. Khongphatthanayothin A, Wong PC, Samara Y, Newth CJ, Starnes VA, Chang AC. Impact of respiratory syncytial virus infection on surgery for congenital heart disease: postoperative course and outcome. Crit Care Med. 1999;27: 1974-81.

7. Li X, Wang X, Li S, Zeng M, Li D. Viral respiratory infection, a risk in pediatric cardiac surgery: a propensity-matched analysis. Pediatr Crit Care Med. 2020;21: e431-40.

8. Altman CA, Englund JA, Demmler G, Drecher KL, Alexander MA, Watrin C, et al. Respiratory syncytial virus in patients with congenital heart disease: a contemporary look at epidemiology and success of preoperative screening. Pediatr Cardiol. 2000;21:433-8.

9. Spaeder MC, Carson KA, Vricella LA, Alejo DE, Holmes KW. Impact of the viral respiratory season on postoperative outcomes in children undergoing cardiac surgery. Pediatr Cardiol. 2011;32:801-6.

10. Moynihan K, Barlow A, Alphonso N, Anderson B, Johnson J, Nourse C, et al Impact of viral respiratory pathogens on outcomes after pediatric cardiac surgery. Pediatr Crit Care Med. 2017;18:219-27.

11. Gaies MG, Gurney JG, Yen AH, Napoli ML, Gajarski RJ, Charpie RG, et al Vasoactive-inotropic score as a predictor of morbidity and mortality in infants after cardiopulmonary bypass. Pediatr Crit Care Med. 2010;11:234-8.

12. Harris PA, Taylor R, Thielke R, Payne J, Gonzalez N, Conde JG. Research electronic data capture (REDCap) — a metadata-driven methodology and workflow process for providing translational research informatics support. J Biomed Inform. 2009;42:377-81.

13. Harris PA, Taylor R, Minor BL, Elliott V, Fernandez M, O'Neal L, et al. REDCap Consortium, the REDCap consortium: building an international community of software partners. J Biomed Inform. 2019;95:103208.

14. Navas L, Wang E, de Carvalho V, Robinson J. Improved outcome of respiratory syncytial virus infection in a high-risk hospitalized population of Canadian children. Pediatric Investigators Collaborative Network on Infections in Canada. $J$ Pediatr. 1992;121:348-54.

15. Moler FW, Khan AS, Meliones JN, Cruster JR, Palmisano J, Shope TC. Respiratory syncytial virus morbidity and mortality estimates in congenital heart disease patients: a recent experience. Crit Care Med. 1992;20:1406-13.

16. Wang EE, Law BJ, Stephens D. Pediatric Investigators Collaborative Network on Infections in Canada (PICNIC) prospective study of risk factors and outcomes in patients hospitalized with respiratory syncytial viral lower respiratory tract infection. J Pediatr. 1995;126:212-9.

17. Becke K. Anesthesia in children with a cold. Curr Opin Anaesthesiol. 2012;25: 333-9.

18. Azakie A, Russell IA. Gender differences in pediatric cardiac surgery: the surgeon's perspective. J Thorac Cardiovasc Surg. 2004;128:4-6.

Key Words: congenital heart disease, viral respiratory tract infections, postoperative outcomes, intensive care units, pediatrics 
TABLE E1. Summary of viral RTI case patients and control patients with comorbidities, respiratory complications, and nonrespiratory complications

\begin{tabular}{|c|c|c|c|}
\hline Patient & Patient comorbidities & $\begin{array}{l}\text { Postoperative } \\
\text { respiratory } \\
\text { complications }\end{array}$ & $\begin{array}{l}\text { Postoperative other } \\
\text { complications }\end{array}$ \\
\hline Case 1 & Malrotation, situs inversus & & $\begin{array}{c}\text { Clot of shunt requiring } \\
\text { revision, ASD stent }\end{array}$ \\
\hline Control A & & & \\
\hline Control B & High-flow nasal cannula (4 L/min), premature $35 \mathrm{wk} \mathrm{GA}$ & & Wound infection \\
\hline $\begin{array}{l}\text { Case } 2 \\
\text { Control A } \\
\text { Control B }\end{array}$ & Status: post-Norwood/Sano/Glenn & & Iliac clot \\
\hline $\begin{array}{l}\text { Case } 3 \\
\text { Control A } \\
\text { Control B }\end{array}$ & $\begin{array}{l}\text { FTT } \\
\text { Trisomy } 21 \\
\text { Trisomy } 21\end{array}$ & & \\
\hline $\begin{array}{l}\text { Case } 4 \\
\text { Control A }\end{array}$ & $\begin{array}{l}\text { CHF } \\
\text { Trisomy 21, FTT, CHF, previous colostomy secondary to necrotizing enterocolitis, } \\
\text { premature } 35 \mathrm{wk} \mathrm{GA}\end{array}$ & VAP & \\
\hline Control B & CHF, right frontal lobe ischemia, junctional rhythm, acute kidney injury & & \\
\hline Case 5 & FTT & & $\begin{array}{l}\text { Junctional ectopic } \\
\text { tachycardia }\end{array}$ \\
\hline $\begin{array}{l}\text { Control A } \\
\text { Control B }\end{array}$ & & VAP & \\
\hline $\begin{array}{l}\text { Case } 6 \\
\text { Control A } \\
\text { Control B }\end{array}$ & $\begin{array}{l}\text { Pulmonary hypertension, FTT, CHF } \\
\text { Pulmonary hypertension }\end{array}$ & & \\
\hline $\begin{array}{l}\text { Case } 7 \\
\text { Control A } \\
\text { Control B }\end{array}$ & $\begin{array}{l}\text { Scimitar syndrome, pulmonary hypertension, chronic BiPAP, FTT, hypoplastic } \\
\text { right lung } \\
\text { 22q11.2 deletion }\end{array}$ & & \\
\hline $\begin{array}{l}\text { Case } 8 \\
\text { Control A } \\
\text { Control B }\end{array}$ & VACTERL association & Chylothorax & $\begin{array}{l}\text { Ventricular } \\
\text { fibrillation arrest } \\
\text { intraoperative } \\
\text { for } 7 \text { minutes }\end{array}$ \\
\hline $\begin{array}{l}\text { Case } 9 \\
\text { Control A } \\
\text { Control B }\end{array}$ & $\begin{array}{l}\text { Radial hypoplasia, absent thumbs, no left ulna, dysplastic fibula, tibial aplasia } \\
\text { Obstructive sleep apnea, anemia, home oxygen } \\
\text { Adrenal insufficiency, neck hemangioma, hyperthyroidism }\end{array}$ & & \\
\hline $\begin{array}{l}\text { Case } 10 \\
\text { Control A } \\
\text { Control B }\end{array}$ & $\begin{array}{l}\text { 22q11.2 deletion } \\
\text { Trisomy 21, hypothyroidism, FTT }\end{array}$ & VAP & \\
\hline Case 11 & 22q11.2 deletion, FTT & $\begin{array}{l}\text { VAP, } \\
\text { diaphragmatic } \\
\text { paralysis }\end{array}$ & \\
\hline $\begin{array}{l}\text { Control A } \\
\text { Control B }\end{array}$ & Pelvic kidney & & \\
\hline Case 12 & Inguinal hernia & & $\begin{array}{l}\text { Cardiac arrest } \times \\
\quad 2 \text { (atrioventricular block) }\end{array}$ \\
\hline Control A & . & $\begin{array}{l}\text { Bilateral } \\
\text { pleural } \\
\text { effusions }\end{array}$ & \\
\hline Control B & CHF, FTT & & \\
\hline
\end{tabular}


TABLE E1. Continued

\begin{tabular}{|c|c|c|c|}
\hline Patient & Patient comorbidities & $\begin{array}{l}\text { Postoperative } \\
\text { respiratory } \\
\text { complications }\end{array}$ & $\begin{array}{l}\text { Postoperative other } \\
\text { complications }\end{array}$ \\
\hline $\begin{array}{l}\text { Case } 13 \\
\text { Control A } \\
\text { Control B }\end{array}$ & FTT & Stridor & \\
\hline $\begin{array}{l}\text { Case } 14 \\
\text { Control A } \\
\text { Control B }\end{array}$ & $\begin{array}{l}\text { Premature } \\
\text { Craniosynostosis }\end{array}$ & Chylothorax & \\
\hline $\begin{array}{l}\text { Case } 15 \\
\text { Control A } \\
\text { Control B }\end{array}$ & $\begin{array}{l}\text { Pentalogy of Cantrell, previous diaphragmatic hernia repair, omphalocele, } \\
\text { dysplastic kidneys } \\
\text { Intrauterine growth restriction, hypospadias }\end{array}$ & & \\
\hline $\begin{array}{l}\text { Case } 16 \\
\text { Control A } \\
\text { Control B }\end{array}$ & $\begin{array}{l}22 \mathrm{q} 11.2 \text { deletion, right femoral clot } \\
22.11 .2 \text { deletion }\end{array}$ & $\begin{array}{l}\text { VAP } \\
\text { Inhaled } \\
\text { nitric oxide } \\
\text { requirement }\end{array}$ & $\begin{array}{l}\text { Junctional } \\
\text { ectopic } \\
\text { tachycardia }\end{array}$ \\
\hline $\begin{array}{l}\text { Case } 17 \\
\text { Control A } \\
\text { Control B }\end{array}$ & $\begin{array}{l}\text { Premature } \\
\text { Premature, CHF }\end{array}$ & $\begin{array}{l}\text { Secretions, stridor, } \\
\text { increased work } \\
\text { of breathing }\end{array}$ & \\
\hline $\begin{array}{l}\text { Case } 18 \\
\text { Control A } \\
\text { Control B }\end{array}$ & $\begin{array}{l}\text { Premature } 29 \text { wk GA, respiratory distress syndrome, inguinal hernia } \\
\text { Pulmonary hypertension (resolved), ear/limb dysmorphism, small kidneys } \\
\text { Premature } 30 \text { wk GA, apnea of premature, hypothyroidism, bilateral inguinal } \\
\text { hernias, hypospadias }\end{array}$ & & \\
\hline $\begin{array}{l}\text { Case } 19 \\
\text { Control A } \\
\text { Control B }\end{array}$ & $\begin{array}{l}\text { Meningocele, laryngomalacia } \\
\text { Premature } 32 \text { wk GA }\end{array}$ & & $\begin{array}{l}\text { Repeat operation: } \\
\text { Subclavian flap }\end{array}$ \\
\hline Case 20 & & $\begin{array}{l}\text { Right diaphragm } \\
\text { paralysis }\end{array}$ & Delirium \\
\hline $\begin{array}{l}\text { Control A } \\
\text { Control B }\end{array}$ & Previous chylothorax, right femoral clot, focal seizures, acute kidney injury & VAP & Acute kidney injury \\
\hline
\end{tabular}

